\title{
Antimicrobial factors in bovine colostrum
}

\author{
HANNU KORHONEN \\ Institute of Dairy Science, University of Helsinki 00710 Helsinki 71
}

\begin{abstract}
The study determined the content of certain antimicrobial proteins in the colostrum of five Ayrshire cows during the first 9 milkings and in milk 14 days from parturition. The following factors were analyzed: total whey protein (WP), total immunoglobulins (Ig), lactoferrin (LF), lactoperoxidase (LP), lysozyme (LZM), and Salmonella typhimurium antibody titer towards somatic $\left(0_{4,12}\right)$ and flagellar $\left(\mathrm{H}_{1.5}, \mathrm{H}_{1}\right)$ antigens.

The content of all factors varied considerably in the first milking of the various cows, but the difference in content for all but LP and LZM decreased along with the number of milkings. The concentrations of WP, Ig and LF were at their highest in the first milking and dropped markedly in the following milkings. On the other hand, the LP concentration was on average greatest during the 3 rd and 4 th milkings, and the LZM concentration during the 7 th and 8 th milkings.

The colostral whey from the first milking had the following concentrations on average: WP $69.2 \mathrm{mg} / \mathrm{ml}$, Ig $52.0 \mathrm{mg} / \mathrm{ml}$, LF $1.53 \mathrm{mg} / \mathrm{ml}$, LP $22.8 \mu \mathrm{g} / \mathrm{ml}$ and LZM $0.40 \mu \mathrm{g} / \mathrm{ml}$. In the milk whey the concentrations were as follows: WP $12.2 \mathrm{mg} / \mathrm{ml}, \mathrm{Ig} 0.95 \mathrm{mg} / \mathrm{ml}$, LF $0.09 \mathrm{mg} / \mathrm{ml}$, LP $20.1 \mu \mathrm{g} / \mathrm{ml}$ and LZM $0.37 \mu \mathrm{g} / \mathrm{ml}$.

Agglutinating antibodies to a human pathogenic strain of S. typhimurium were found against both $\mathrm{O}$ and $\mathrm{H}$ antigens in the colostrum of all cows. One cow, which had been vaccinated with $S$. typhimurium before parturition, had significantly higher titers than the unvaccinated animals. The latter were found to have antibodies only in the first two or three milkings post partum while the vaccinated cow still had antibodies in the milk 14 days post partum. The results obtained permit the assumption that in addition to antibodies, the nonspecific antibacterial factors (LF, LP and LZM) may contribute to the antimicrobial activity of colostrum and thus enhance the resistance of a newborn calf to microbial infections during the first week of life.
\end{abstract}

\section{Introduction}

The significance of colostrum for the health of a newborn calf during its first days of life is well known. According to numerous studies, the effect of colostrum against microbial infections in calf is based primarily on antibodies, or immunoglobulins ( $\mathrm{Ig}$ ), whose content is high in the first milkings after parturition (Dixon et al. 1961, Fey 1972, Butler 1974, Logan 1974, Kolb 1975, Porter 1976). In addition to antibodies, bovine mammary secretions 
also contain other antimicrobial factors, the best known of which are leukocytes, lactoferrin (LF), lysozyme (LZM) and the inhibitory system catalyzed by lactoperoxidase (LP) (REITER and Oram 1967, Korhonen 1973, Reiter 1976). Many attempts have been made in recent years to determine the significance of these natural antimicrobial factors with regard to combatting udder infections (Reiter and Oram 1967, Korhonen 1973, Reiter and Bramley 1975, Norcross 1977, PaApe and Wergin 1977, Smith and Schanbacher 1977). With the exception of immunoglobulins and antibodies, only the content of lactoferrin in colostrum has been studied to any great extent (SENFT and Klobasa 1973, Senft et al. 1976, Welty et al. 1976, Klobasa et al. 1977). The possible significance of lactoferrin, lactoperoxidase, lysozyme and cells for infection resistance in newborn calves has not been studied closely.

The purpose of this study was to determine preliminarily the content of the known humoral antimicrobial factors in the colostrum of various cows and changes in content as lactation begins.

\section{Material and methods}

\section{Samples}

Colostrum samples were taken from five Ayrshire cows, four of which were part of the same herd. Two of the cows (Esi and Alku) calved for the first time, an additional two (Aija and Äpä) for the second time, and one (Pakka) for the eighth time during the study period. The samples were taken from the first to the ninth milkings after parturition. The cows were milked twice daily. A single sample of milk was also obtained 14 days after parturition. The samples were collected from each quarter and were combined for the determinations. The samples were frozen immediately after sampling in sterile plastic bottles and stored at $-20^{\circ} \mathrm{C}$ until all the samples had been collected. The maximum storage time for the samples was 30 days.

For analysis, fat was removed from the melted samples by centrifugation and casein by coagulation (KorHONEN and Antila 1977). The whey was filtered through a Millipore filter and the clear whey was used immediately for the determinations.

\section{Determinations}

Total whey protein (WP) content

The determination was carried out colorimetrically by adapting the biuret reaction and using a commercial reagent kit (Sigma Chem. Co, St. Louis, Mo.). The extinction was measured in this determination and for LZM and LP using a Hitachi Perkin-Elmer UV VIS-139 spectrophotometer.

Total amount of immunoglobulins

The determination was carried out using the radial immunodiffusion technique presented by FAHEY and McKelvey (1965). Commercial antibovine-serum- $\boldsymbol{\gamma}$-globulin serum (Behringwerke AG, Marburg/Lahn) was used 
as the antiserum. The whey samples were diluted with a $0.01 \mathrm{M}$ sodium phosphate buffer ( $\mathrm{pH}$ 7.4). Standard solutions were made in the same buffer from commercial bovine serum- $\gamma$-globulin (Serva Feinbiochemica, Heidelberg).

\section{L a c t of errin content}

The determination was carried out with radial immunodiffusion in the same way as the determination of Ig. An antiserum to lactoferrin was produced in rabbits using an LF preparation purified from colostrum as the antigen (Korhonen and Ahonen 1977). The same preparation was used as the standard in the determination.

Lactoperoxidase content

The determination was carried out colorimetrically using 0-dianisidine as the reagent. The method has been described in detail elsewhere (KoRHONEN et al. $1977 \mathrm{c})$.

\section{L y s o y m e content}

The determination was carried out turbidimetrically using the technique described by PARRY et al. (1965), which was adapted in the manner described previously (Korhonen 1973). Crystalline egg white lysozyme (Difco, Detroit, Mich.) was used as the standard.

\section{Salmonella typhimurium}

Antibody titer

Since one of the cows (Alku) had been inoculated subcutaneously with humanpathogenic Salmonella typhimurium vaccine about a month before parturition for another study (KorHONEN et al. $1977 \mathrm{~b}$ ), the occurrence of S. typhimurium antibodies in the colostrum of this cow and unvaccinated cows was studied. Classic agglutination titration was used in the determination, carried out using specific $\mathrm{O}_{4,12}, \mathrm{H}_{1,5}$ and iantigen suspensions on microtiter plates. The titration technique has been described previously (KorHoNEN et al. 1977 b).

\section{Results}

Figures $1 \mathrm{a}$ and $\mathrm{b}$ present the results for total whey proteins and the contents of various antimicrobial factors in the colostrum of five cows during nine successive milkings and in their milk 14 days after parturition. Table 1 presents the arithmetic means and ranges of the same parameters during different milkings. The results show that the amounts of WP, Ig and LF are highest in the first milking. However, the contents drop markedly as early as in the second or third milking. In the fourth milking the amount of WP is on average $27.9 \%$, the amount of $\mathrm{Ig} 8.8 \%$ and of LF $12.4 \%$ of the content during the first milking. There is only a slight drop in the amounts during the fifth to ninth milkings, but the amounts in the milk sample taken 14 days 
after parturition have dropped even farther, showing that colostrum changes fairly slowly (over $\mathbf{5}$ days) into milk similar to that produced during the normal lactation period. Figure $1 \mathrm{~b}$ shows that in contrast to Ig and LF, the content of enzymatically active proteins, LP and LZM, generally rises after the first milking, and then gradually drops as the milk secretion becomes normal. The maximum LP content is found on average during the third and fourth milkings while the maximum LZM content is found in the colostrum during the seventh and eight milkings (Table 1). On the basis of means, the contents of both enzymes clearly drop as normal lactation begins, though marked individual difference can be noted.

A comparison of the contents of the antimicrobial proteins tested in various cows shows that there are considerable individual differences for all factors. The ranges of Ig and LF content of the colostrum of various cows do, however, decrease along with the number of milkings, while individual differences for LP and LZM seem to remain large even in milk. Immunoglobulins are the most abundant of the antimicrobial factors studied in both colostrum and milk. Ig accounts for an average of $75 \%$ of the total amount on WP in the 1st milking, but the relative proportion decreases rapidly in the following milkings. In the 4 th milking it is only $23.8 \%$ and in the 9 th milking $11.2 \%$. In milk 14 days post partum the corresponding figure is $7.8 \%$. The LF content in the 1st milking is $1 / 30$ th that of the Ig content, but the ratio decreases along with milkings and in milk the content difference is about 1/10th. Marked differences between individuals can be seen especially in the LF content during the 1st and 2nd milkings. The LP and LZM contents are in the range of $\mu \mathrm{g} / \mathrm{ml}$, and thus are $1 / 100$ to $1 / 1000$ those of Ig and LF. The content of lysozyme in colostrum is at most only in the range of $1 \mu \mathrm{g} / \mathrm{ml}$, and is thus $1 / 40$ to $1 / 80$ that of the content of lactoperoxidase during the same milking. On the other hand, there are marked variations among individuals in the relationship between LP and LZM.

A comparison of the amounts of the proteins studied in the colostrum of the first milking with regard to the cow's number of lactations shows that the Ig and LF contents are clearly lower in animals calving for the first time (Esi and Alku) than in others. No differences are found, however, in the amounts of LP and LZM.

Figure 2 shows the occurrence of agglutinating S. typhimurium antibodies in the mammary gland secretions of various cows after parturition. The figure shows that the colostrum of all the cows has these antibodies in varying titers towards various antigens. Antibodies are found in a small titer in the colostrum of unvaccinated cows during the 1st-3rd milkings, but not thereafter. On the other hand, the antibody titers in the colostrum of the vaccinated cow are clearly higher than those of the other cows. Both $\mathrm{O}$ ja $\mathrm{H}$ antibodies are still found during the 9 th milking and small titers of $\mathrm{O}$ and $\mathrm{H}$ antibodies are also found in milk. $\mathrm{H}$ antibodies dominate in the colostrum of both the vaccinated cow and the unvaccinated cows. 

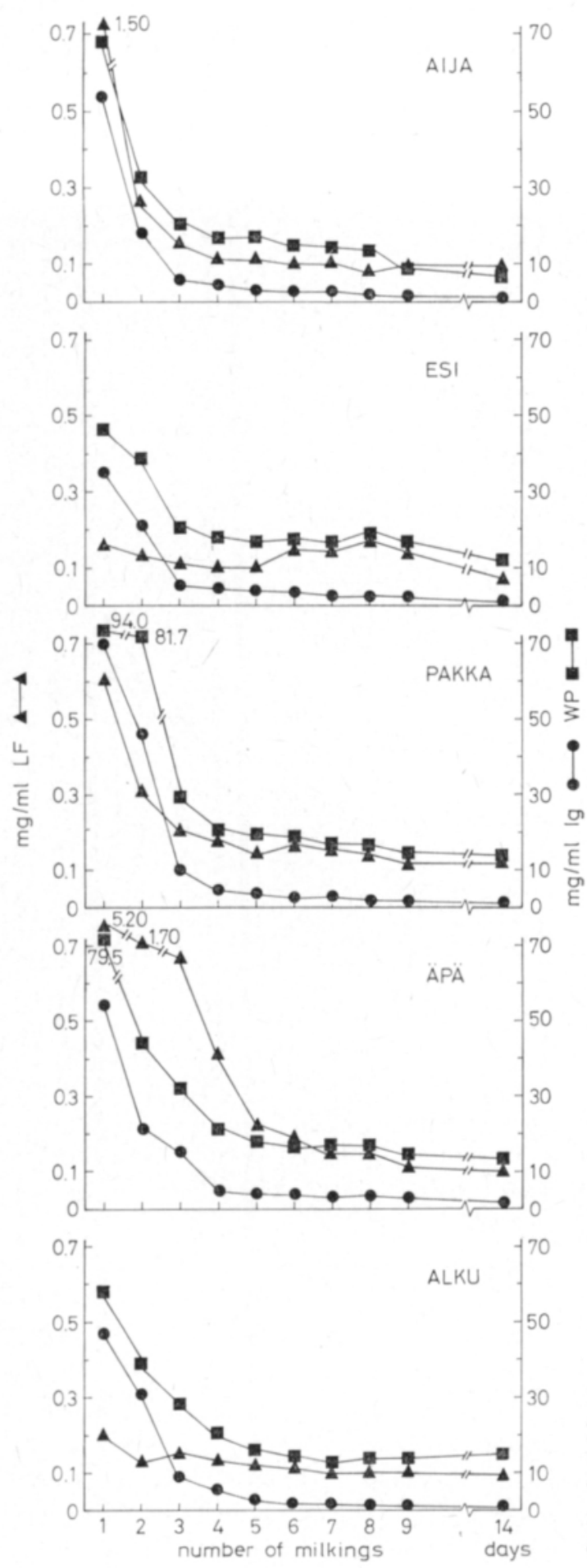

Figure 1 a. Concentrations of total whey protein (WP), total immunoglobulins (Ig) and lacto ferrin (LF) in the colostral whey of five cows during the first nine milkings and in the milk whey after 14 days from parturition. 

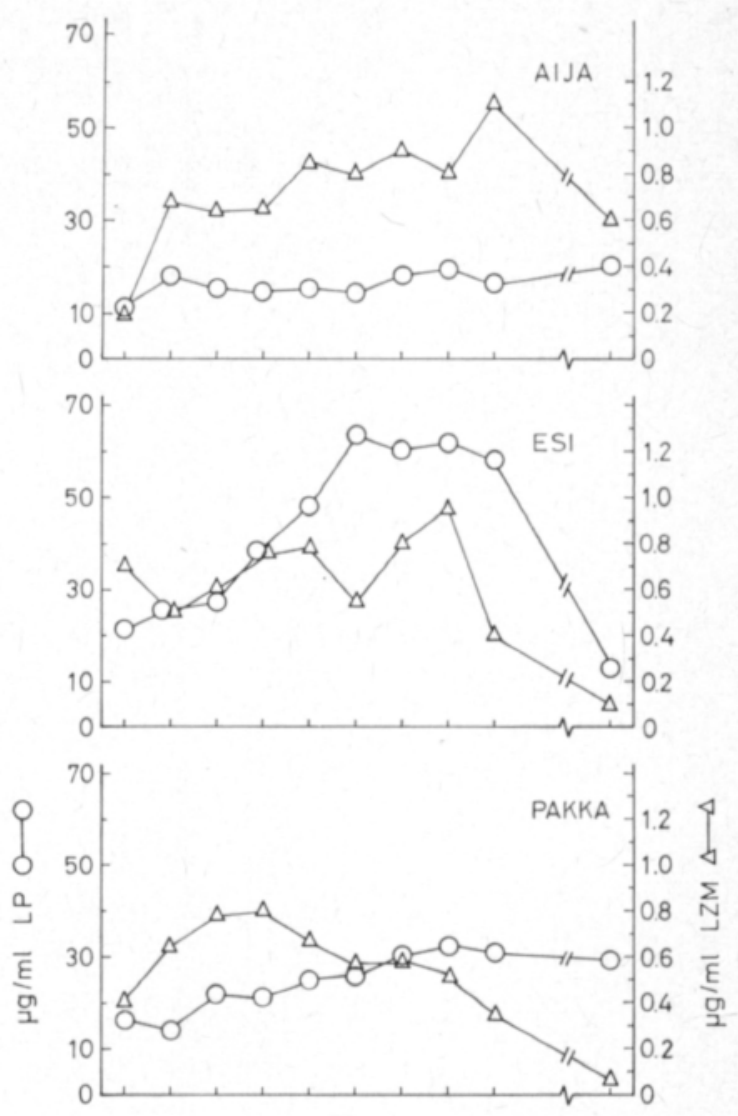

Figure $1 \mathrm{~b}$. Concentrations of lactoperoxidase (LP) and lysozyme (LZM) in the colostral whey of five cows during the first nine milkings and in the milk whey after 14 days from parturition.

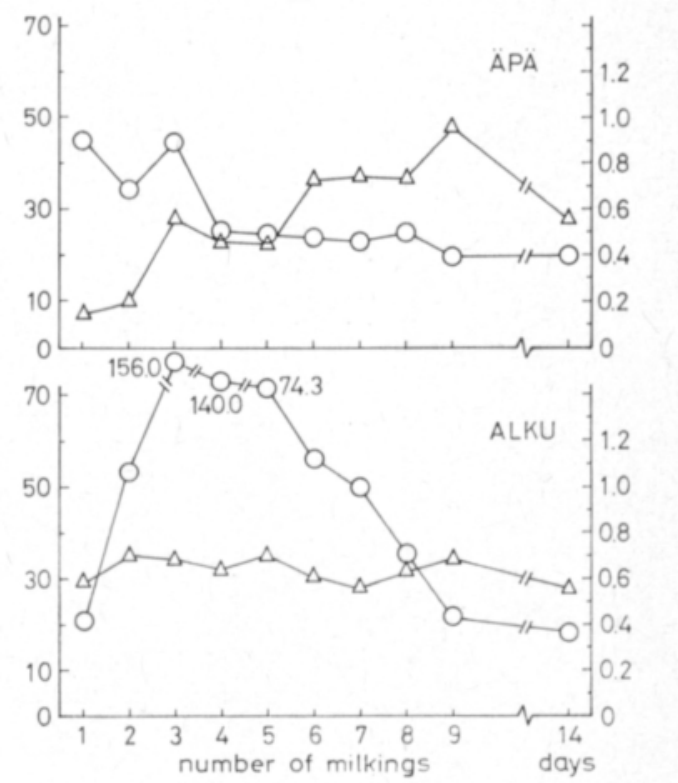




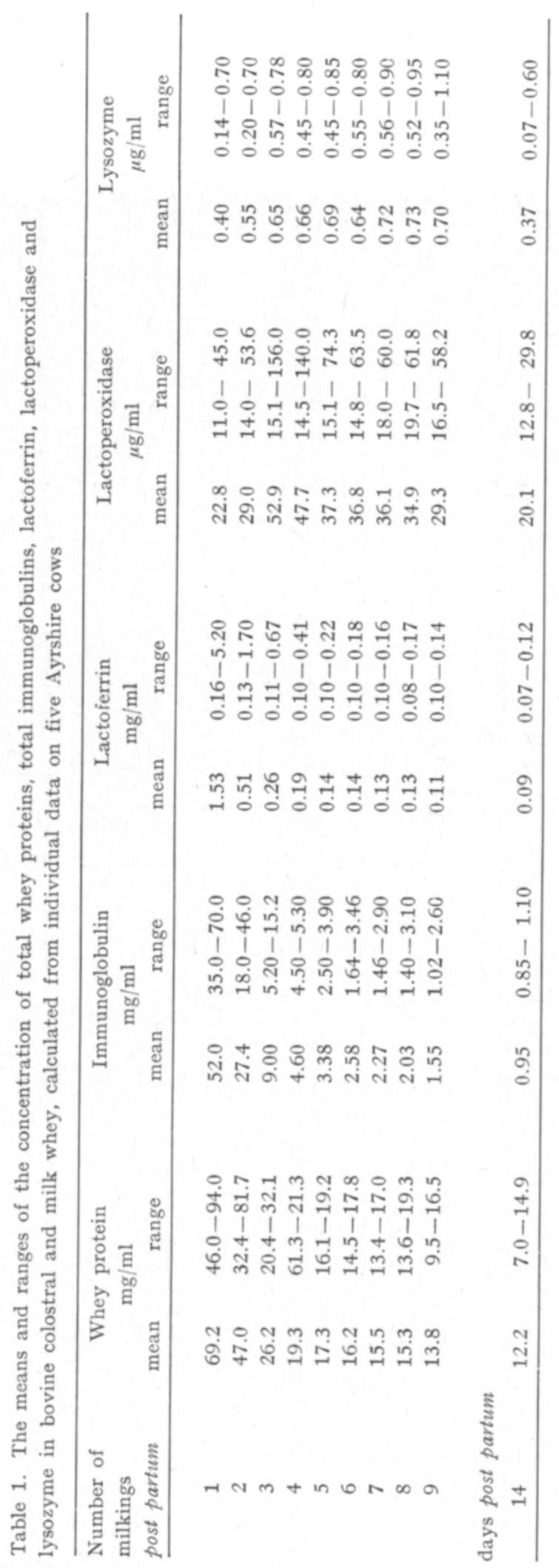



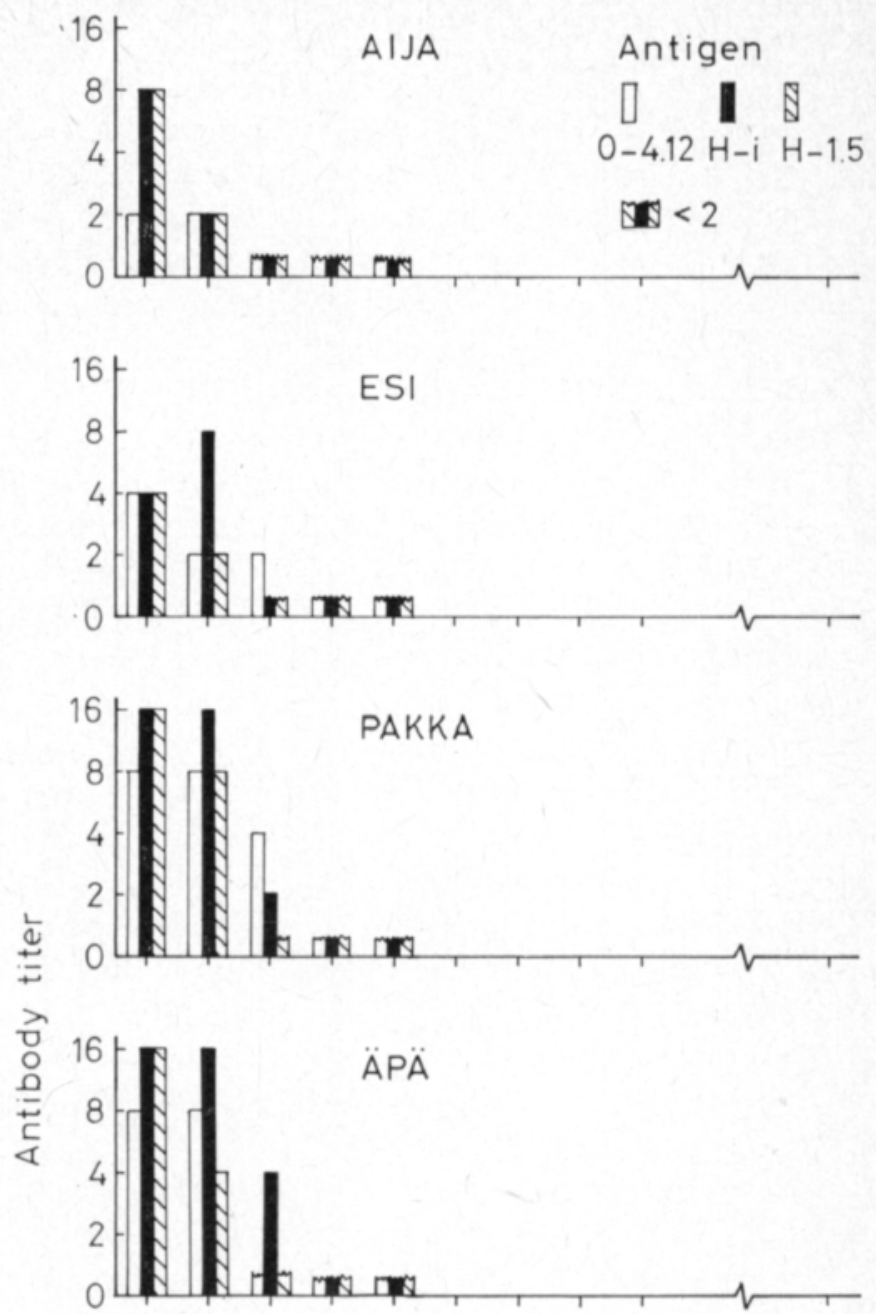

Figure 2. Salmonella typhimurium antibody titers towards $\mathrm{O}_{4,12}, \mathrm{H}_{\mathrm{i}}$ and $\mathrm{H}_{1,5}$ antigens in the colostral whey of five cows during the first nine milkings and in the milk whey after 14 days from parturition. The cow ALKU was vaccinated with a S. typhimurium vaccine subcutaneously 27, 23 and 21 days before parturition.

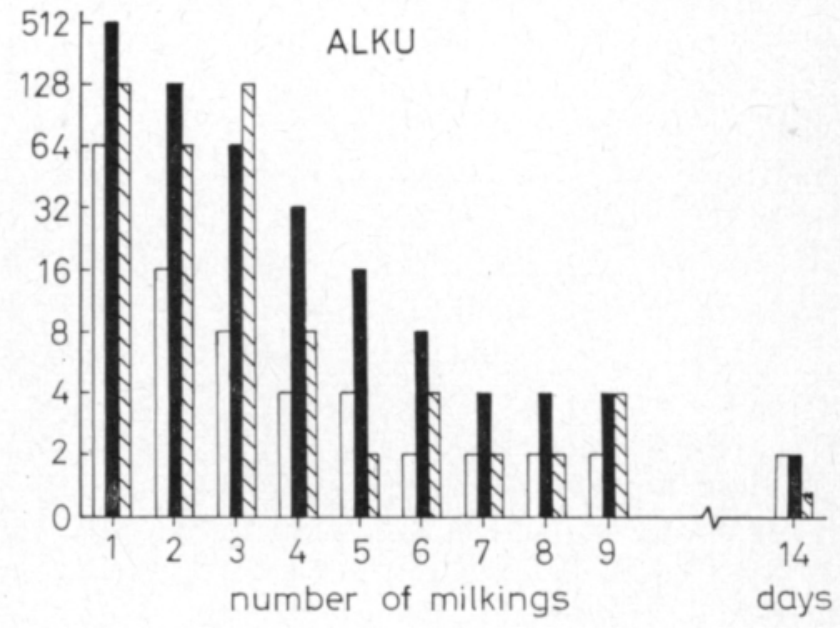




\section{Discussion}

The composition of the whey proteins in bovine mammary secretions differs considerably during different functional states of the mammary gland (Schanbacher and Sмith 1975). In normal milk the main whey proteins are $\alpha$-lactalbumin and $\beta$-lactoglobulin, which are synthesized in the udder. However, their content rises only slightly during involution (Sмгтн et al. 1971). The Ig and LF contents, on thə other hand, rise markedly in the involuted udder (Smith et al. 1971, Welty et al. 1976). LF may be the main protein component in the dry udder secretion, even exceeding a content of $100 \mathrm{mg} / \mathrm{ml}$ (WELTY et al. 1976). Before parturition, the LF content does, however, drop and varies in the colostrum between 1 and $5 \mathrm{mg} / \mathrm{ml}$ (Senft and Klobasa 1973, Senft et al. 1976, Welty et al. 1976). In milk LF varies between $0,04-1,33 \mathrm{mg} / \mathrm{ml}$, according to various studies (SEnft and KLOBASA 1973, Harmon et al. 1975, Korhonen et al. 1977 a). Most of the lactoferrin is probably synthesized in the secretory epithelial cells of the mammary gland (Schanbacher and SMith 1975, WeLtY et al. 1976), but the PMN leukocytes infiltrated from blood into the mammary gland may also affect the LF content of milk since they produce this iron-binding protein (HARMON et al. 1976, KORHONEN and REITER 1977). LF thus accumulates in the udder and the high content in the 1st and 2nd milkings after parturition is explained by this effect. Even though it has not been possible to fully determine the biological function of LF, several observations have shown that it may play an important role in the physiological defense mechanism of the udder against microbial infections during the involution period (Reiter and Bramley 1975, Bishop et al. 1976, Harmon et al. 1976, Smith and Schanbacher 1977).

In a contrast to LF, most of the immunoglobulins in bovine colostrum originate in the blood (LARSON 1958, Dixon et al. 1961). The transportation of the Ig's takes place selectively with $\mathrm{IgG}_{1}$ being the dominant Ig class in the colostrum (Butler 1974, LAscelles and McDowell 1974, SASAKI et al. 1976). Small amounts of Ig are, however, produced locally in the udder tissue (MAcH and Pahud 1971, Butler et al. 1972, Newby and Bourne 1977).

The results obtained in this work on the total amount of $\mathrm{Ig}$ in the first milking after parturition, on the rapid reduction in the amount in the following milkings, and on the content found in milk, correspond to the results presented in most of the literature (Drxon et al. 1961, Butler 1971, Porter 1972, Butler 1974). It is significant that the antiserum used in this study primarily measures the content of $\mathrm{IgG}_{1}$ and $\mathrm{IgG}_{2}$, as a result of which the IgM and IgA content in colostrum and milk are evidently not measured. Their share is, however, considerably smaller than that of $\operatorname{IgG}_{1}$ (ButLer 1974). The results on the LF concentration also correspond to the values given in the previous studies cited in this paper. The great variations in the $\mathrm{Ig}$ and LF content in various cows during the first milking may be due partly to the lactation number, an observation made by KLOBASA et al. (1977). According to these researchers, hereditary factors may also be involved in the varying amounts of these proteins.

No results enabling a direct comparison have been presented in the literature on the concentration of LP in bovine colostrum. The LZM content found in 
this study corresponds to the ranges given in the studies by PANFIL - K UNCEWICZ and KiszA (1976) and GöTzE et al. (1977). The content of both enzymes are on average higher in colostrum than in milk, but the maximum concentration is not found in the 1st or 2nd milkings, as is the case with Ig and LF. The average concentrations of these enzymes found in milk 14 days post partum are a little higher than the values presented in the literature for LP (KORHONEN et al. $1977 \mathrm{c}$ ) and LZM (Shahani et al. 1962, Korhonen 1973, Janota-Bassalik et al. 1975, Panfil-Kuncewicz and Kisza 1976), but the ranges of variation are of the same magnitude GöTzE et al. (1977), instead, found on average a double higher concentrations of LZM in the milk after two weeks from parturition and the content increased up to the 13 th week of lactation. The origin of LP and LZM in the mammary secretions has not been determined with certainty, but at least LP is considered to be a secretory enzyme which is synthesized in the udder (TAYLOR and KITCHEN 1970). GöTZE et al. (1977) found no correlation between LZM concentration in the blood and in the milk, which suggests that it is synthesized mainly in the udder tissue. On the other hand, an udder infection or secretory disturbance is known to increase the LZM content in milk (Korhonen 1973, JANOTA-BASSAlik et al. 1975, GötZE et al. 1977). Leukocytes in the blood or milk do not, however, contain lysozyme activity (PADGETT and Hirsch 1967) although they possess peroxidase activity (KORHONEN and REITER 1977) and produce lactoferrin (HARMON et al. 1976, Korhonen and REITER 1977). The results obtained indicate that LP and LZM do not accumulate in the udder during the involution period as do Ig and LF. Instead, their secretion is evidently intensified immediately after parturition, and this stage lasts until the normal secretion of the mammary gland begins. The observations of KIERMEIER and KAYSER (1960) on the LP activity of colostrum support this assumption.

The small titers of Salmonella typhimurium antibodies (Figure 2) are a sign of the occurrence of natural antibodies in colostrum. These antibodies may either be formed as the result of an asymptomatic Salmonella infection in the animal, or else are cross-reacting antibodies to some other organisms, which have common antigens with the Salmonella strain used. The former assumption is supported by numerous observations on the occurrence of natural, agglutinating, bactericidal or neutralizing antibodies in bovine colostrum or blood against various bacteria, e.g. Escherichia coli (Ingram and Malcomsen 1970, Porter 1972, Reiter and Brock 1975, Seto et al. 1976), against viruses (WoOdE et al. 1975), and against rumen microbes (SHARPE et al. 1969). The latter assumption is supported by the observation of SHARPE and REITER (1972) that rumen microbes have cross-reacting antigens to salmonellae.

The results obtained also show that the content of specific antibodies in colostrum can be increased with subcutaneous vaccination before parturition. E.g. in this way the passive immune resistance of the newborn calf can be strengthened against certain pathogenic microbes. This concept is confirmed by several vaccination experiments carried out in recent years with pathogenic E. coli bacteria (GAY 1971, Myers et al. 1973, Wilson and Jutila 1976 a, b), and with viruses (Mebus et al. 1973, Woode and Bridger 1975, McNulty et al. 1976). 
The importance of antibodies for the infection resistance of newborn calves has been well documented, and their significance is emphasized by what is still a high content in the colostrum. The absorption of active antibodies from the calf's intestinal tract into the circulation is, however, limited to the period within about 24-36 hours of birth (BRAmbell 1970, Logan 1974). According to the studies of LogAN et al. (1974), colostral Ig preparations (IgA, IgG and IgM) were found to be individually less effective than whole colostrum against colibacillosis in calves, which supports the idea that also other antimicrobial factors in colostrum may have importance to the calf's health. The results obtained in this study give theoretical support to this suggestion since colostrum was found to contain varying amounts - but still clearly higher than milk of nonspecific bactericidal or bacteriostatic factors such as LF, LZM and LP. Since LF (Bullen et al. 1972) and LZM (Adinolfi et al. 1966, Wilson and Spitznagel 1968, Hill and Porter 1974) are known to increase the activity of antibodies in vitro, it is assumed that these proteins do the same in colostrum and maybe active in vivo, too. On the basis of the results obtained, one can conclude that the rapid drop in the amount of natural antibodies, Ig and LF in colostrum after parturition is compensated for by the clear rise in the amount of enzymatic antibacterial proteins, LP and LZM, for the whole colostrum period. In this way the total antimicrobial action of colostrum might remain the same, and through colostrum ingestion give the calf sufficient passive protection against microbial infections during the first week of life. The antibacterial properties of $\mathrm{LF}$ and $\mathrm{LP} / \mathrm{SCN}^{-} / \mathrm{H}_{2} \mathrm{O}_{2}$ system in bovine colostrum and milk are recently substantiated by REITER and his co-workers (REITER et al. 1975, REITER et al. 1976). Their studies give strong support to the role of LF and LP system in the defense against enteric infections in neonates, although at present no conclusive evidence in vivo is available. This and the possible importance of colostral cells remain to be elucitated.

\section{REFERENCES}

Adinolfi, M., Glynn, A. A., Lindsay, M. and Milne, C. M. 1966. Serological properties of $\gamma \mathrm{A}$ antibodies to Escherichia coli present in human colostrum. Immunology 10: 517.

Bishop, J. G., Schanbacher, F. L., Ferguson, L. C. and Smith, K. L. 1976. In vitro growth inhibition of mastitis causing coliform bacteria by bovine apo-lactoferrin and reversal of inhibition by citrate and high concentrations of apo-lactoferrin. Infect. Immun. 14: 911.

Brambell, F. W. R. 1970. The transmission of passive immunity from mother to young. Frontiers of Biology, vol. 18. North-Holland Publ. Co. Amsterdam, London.

Bullen, J. J. Rogers H. J. and Leigh L. 1972. Iron-binding proteins in milk and resistance to Escherichia coli infection in infants. Br. Med. J. 1: 69.

Butler J. E. 1971. A review of the bovine immunoglobulins. J. Dairy Sci. 54: 1315.

,- 1974 . Immunoglobulins of the mammary secretions. In: Lactation. A comprehensive treatise. Vol. III. Ed. by B. L. Larson and V. R. Smith. Academic Press, New York.

- - , Maxwell, C. F., Pierce, C. S., Hylton, M. B., Asofsky, R. and Kiddy, C. A. 1972. Studies on the relative synthesis and distribution of IgA and IgG1 in various tissues and body fluids of the cow. J. Immun. 109: 38 .

Dixon, F. J., Weigle, W. O. and VAzQuez, J. J. 1961. Metabolism and mammary secretion of serum proteins in the cow. Lab. Invest. 10: 216. 
FAHEY, J. L. and MCKelveY. E. M. 1965. Quantitative determination of serum immunoglobulins in antibody-agar plates. J. Immun. 94:84.

FEY, H. 1972. Colibacillosis in calves. Verlag Hans Huber, Bern, Stuttgart, Wien.

GAY, C. C. 1971. Problems of immunization in the control of Escherichia coli infection. Ann. New York Acad. Sci. 176: 336.

Götze, P., Meyer, J. and Buschmann, H. 1977. Untersuchungen über den Lysozymgehalt im Blut und in der Milch von gesunden und euterkranken Rindern. Zbl. Vet. Med. B, 24: 560 .

Harmon, J., Schanbacher, F. L., Ferguson, L. C. and Smith, K. L. 1975. Concentration of lactoferrin in milk of normal lactating cows and changes occurring during mastitis. Am. J. Vet. Res. 36: 1001.

Harmon, R. J., Schanbacher, F. L., Ferguson, L. C. and Smith, K. L. 1976. Changes in lactoferrin, immunoglobulin G. bovine serum albumin and $a$-lactalbumin during acute experimental and natural coliform mastitis in cows. Infect. Immun. 13: 533.

Hill, I. R. and Porter, P. 1974. Studies of bactericidal activity to E. coli of porcine serum and colostral immunoglobulins and the role of lysozyme with secretory IgA. Immunology 26: 1239 .

Ingram, D. G. and Malcomsen, M. R. 1970. Antibodies to E. coli in young calves: O antigens. Am. J. Vet. Res. 31: 61.

Janota-Bassalik, L., Piotrowska, E. Zajac, M. and Wojtaszeriewicz, M. 1975. Studies upon resistance factors in the mammary gland of the cow. II. Lysozyme (muramidase) in cow's milk from udders experimentally infected with Streptococcus agalactiae. Prace i Materialy Zootechniczne 8:125.

Kiermeier, F, and KAYser, C. 1960. Zur Kenntnis der Lactoperoxydase. I Mitt. Verteilung der Lactoperoxydase-Aktivität in Kuhmilch und Abhängigkeit von biologischen Einflüssen. Z. Lebensm.-Unters. - Forsch. 112: 481-498.

Klobasa, F., Senft, B., Meyer, F. and Pfleiderer, U. E. 1977. Untersuchungen über Lactoferrin und Immunglobulin $\mathrm{G}$ in der Kuhmilch. 2. Mitteilung. Züchtungskunde 49: 110 ,

Kolв, E. 1975. Neuere Erkenntnisse zur Biosynthese, Struktur und Funktion der Immunoglobuline beim Rind und Schwein, unter besonderer Berücksichtigung der Bedeutung. der Immunglobuline des Kolostrums für die Senkung der Jungtierverluste. Mh. Vet Med. 30: 73.

Korhonen, H. 1973. Untersuchungen zur Bakterizidie der Milch und Immunisierung der bovinen Milchdrüse. Meijeritiet. Aikakausk. (Finnish J. Dairy Sci.) 32: (3) 1-158.

- - - and AHonen, T. 1977. To be published.

- - , Ahonen, T. and Antils, M. 1977 a. Lactoferrin content of the finnish bovine milk. 20th Int. Dairy Congr. Proc. (in press).

- - and Antil A, M. 1977. Uber die Immunantwort des Rindes auf die Impfung mit Clostridium tyrobutyricum -Vakzine. Meijeritiet. Aikakausk. (Finnish J. Dairy Sci.) 35: (1) 66.

- - - , Antila, M., Halinen, K. and Kouvalainen, K. 1977 b. Untersuchungen zur Erzeugung von Salmonella typhimurium- -Antikörpern in Milchkühen und Herstellung von Antikörperpräparaten. Meijeritiet. Aikakausk. (Finnish J. Dairy Sci.) 35: (1) 1 .

- - , Rintamãki, O. and Antila, M. 1977 c. A polyol mixture or molasses treated beet pulp in the silage based diet of dairy cows. II. The effect on the lactoperoxidase and thiocyanate content of milk and the udder health. J. Sci. Agric. Soc. Finl. 49:330-345.

- - and ReITER, B. 1977. Unpublished results.

LARson, B. L. 1958. Transfer of specific blood serum proteins to lacteal secretions near parturition. J. Dairy Sci. 41:1033.

Lascelles, A. K. and McDowell, G. H. 1974. Localised humoral immunity with special reference to ruminants. Transpl. Rev. 19: 170 .

LoGAN, E. F. 1974. Colostral immunity to colibacillosis in the neonatal calf. Br. Vet. J. 130: 405.

- - , Stenhouse, A. and Ormrod, D. J. 1974. The role of colostral immunoglobulins in intestinal immunity to enteric colibacillosis in the calf. Res. Vet. Sci. 17: 290. 
MACH, J.-P. and PAHUD, J.-J. 1971. Secretory IgA, a major immunoglobulin in most bovine external secretions. J. Immun. 106: 552.

McNulty, M. S., McFerran, J. B., Bruson, D. G., Logan, E. F. and Curran, W. L. 1976. Studies on rotavirus infection and diarrhoea in young calves. Vet. Rec. 99: 229.

Mebus, C. A., White, R. G., Bass, E. P., Twiehaus, M. J. 1973. Immunity to neonatal calf diarrhoea virus. J. Am. Vet. Med. Ass. 163: 880.

Myers, L. L., Newman, F. S., Wilson, R. A. and Catlin, J. E. 1973. Passive immunization of calves against experimentally induced enteric colibacillosis by vaccination of dams. Am. J. Vet. Res. 34: 29.

Newby, T. J. and Bourne, J. 1977. The nature of the local immune system of the bovine mammary gland. J. Immun. 118: 461.

Norcross, N. L. 1977. Immune response of the mammary gland and role of immunization in mastitis control. J. Am. Vet. Med. Ass. 170: 1228.

PaApe, M. J. and Wergin, W. P. 1977. The leucocyte as a defense mechanism. J. Am. Vet. Med. Ass. 170: 1214 .

Padgett, G. A. and Hirsch, J. G. 1967. Lysozyme: its absence in tears and leucocytes of cattle. Aust. J. exp. Biol. med. Sci. 45: 569.

Panfil-Kuncewicz, H. and Kisza, J. 1976. Study of lysozyme content in human and cow's milk. Zeszyty Naukowe Akademii Rolniczo-Technicznej w Olsztynie 151: 105-112, ref. Dairy Sci. Abstr. 39 (2): 119, 1977.

Parry, R. M. Jr., Chandan, R. C. and Shahani, K. M. 1965. A rapid and sensitive assay of muramidase. Proc. Soc. exp. Biol. Med. 119: 384.

Porter, P. 1972. Immunoglobulins in bovine mammary secretions. Quantitative changes in early lactation and absorption by the neonatal calf. Immunology 23: 225 .

- -1976 . Immunoglobulin mechanisms in health and nutrition from birth to weaning. Proc. Nutr. Soc. 35: 273.

REITER, B. 1976. Bacterial inhibitors in milk and other biological secretions, with special reference to the complement/antibody, transferrin/lactoferrin and lactoperoxidase/ thiocyanate/hydrogen peroxide systems. In: Inhibition and inactivation of vegetative microbes. pp. 31-60. Eds. F. A. Skinner and W. B. Hugo, Academic Press, London.

- - and Bramley, A. J. 1975. Defence mechanisms of the udder and their relevance to mastitis control. In: Proceedings of a Seminar on Mastitis Control, IDF Doc. 85, 210.

- - and Brock, J. H. 1975. Inhibition of Escherichia coli by bovine colostrum and postcolostral milk. I. Complement-mediated bactericidal activity of antibodies to a serum susceptible strain of $E$. coli of the serotype O 111. Immunology 28: 71.

- - Brock, J. H. and Steel. E. D. 1975. Inhibition of Escherichia coli by bovine colostrum and post-coloctral milk. II. The bacteriostatic effect of lactoferrin on a serum susceptible and serum resistant strain of E. coli. Immunology 28: 83.

- - B., Marshall, V. M. E., BJörck, L. and Rosén, C.-G. 1976. Nonspecific bactericidal activity of the lactoperoxidase-thiocyanate-hydrogen peroxide system of milk against Escherichia coli and some gram-negative pathogens. Infect. Immun. 13: 800 .

- - and Oram, J. D. 1957. Bacterial inhibitors in milk and other biological fluids. Nature, London, 216: 328.

Sasaki, M., Davis, C. L. and Larson, B. L. 1976. Production and turnover of IgG1 and IgG2 immunoglobulins in the bovine around parturition. J. Dairy Sci. 59: 2046.

Schanbacher, F. L. and Smith, K. L. 1975. Formation and role of unusual whey proteins and enzymes: Relation to mammary function. J. Dairy Sci. 58: 1048.

Senft, B. and Klobasa, F. 1973. Untersuchungen über die Konzentration an Lactoferrin in Kolostralmilch und reifer Milch von Kühen. Milchwissenschaft 28:750.

- - , Klobasa, F., Meyer, F. and Pfleiderer, U. E. 1976. Untersuchungen über Lactoferrin und Immunglobulin $\mathrm{G}$ in der Kuhmilch. I. Mitteilung. Züchtungskunde 48: 278.

Seto, A., Окаве, T., Sasaki, N. and Iтo, Y. 1976. Opsonic activity and O agglutinins against Escherichia coli in bovine colostrum. Am. J. Vet. Res. 37: 635.

Shahani, K. M., Chandan, R. C., Kelly, P. L. and Macouiddy, Sr. E. L. 1962. Determination of lysozyme in milk and factors affecting its concentration and properties. 16th Int. Dairy Congr., København, C: 285. 
Sharpe, M. E., Latham, M. J. and Reiter, B. 1969. The occurrence of natural antibodies to rumen bacteria. J. Gen. Microb. 56: 353.

Sharpe, M. E. and Reiter, B. 1972. Common antigenic determinant in a rumen organism and in salmonellae containing the antigen 04. Appl. Microbiol. 24:613.

Smith, K. L., Conrad, H. R. and Porter, R. M. 1971. Lactoferrin and IgG immunoglobulins from involuted bovine mammary glands. J. Dairy Sci. 54: 1427.

- - and Schanbacher, F. L. 1977. Lactoferrin as a factor of resistance to infection of the bovine mammary gland. J. Am. Vet. Med. Ass. 170: 1224.

TAYlor, G. C. and Kitchen, B. J. 1970. Enzyme levels in mastitis milk. 18th Int. Dairy Congr., Sydney, 1 E: 624.

Welty, F. K., Sмith, K. L. and Schanbacher, F. L. 1976. Lactoferrin concentration during involution of the bovine mammary gland. J. Dairy Sci. 59: 224.

Wilson, R. A. and Jutrla, J. W. 1976. Experimental neonatal colibacillosis in cows: a) Serological studies. Infect. Immun. 13: 92, b) Immunoglobulin classes involved in protection. Infect. Immun. 13: 100.

Wilson, L. A. and Spitznagel, J. K. 1968. Molecular and structural damage to Escherichia coli produced by antibody, complement and lysozyme systems. J. Bact. 96: 1339.

Woode, G. N. and Bridger, J. C. 1975. Viral enteritis of calves. Vet. Rec. 96: 85.

- - , Jones, J. and BRIDGER, J. C. 1975. Levels of colostral antibodies against neonatal calf diarrhoea virus. Vet. Rec. 97: 148.

Ms received January $10,1978$.

\title{
SELOSTUS
}

\section{Antimikrobiellit tekijät lehmän ternimaidossa}

\author{
Hannu Korhonen \\ Helsingin yliopiston maitotalouslaitos, 00710 Helsinki 71
}

Tutkimuksessa selvitettiin eräiden luonnollisten, antimikrobisia ominaisuuksia omaavien proteiinien pitoisuutta viiden Ayrshire-lehmän ternimaidossa 9 ensimmäisellä lypsykerralla ja maidossa 14 vrk:n kuluttua poikimisesta. Seuraavat tekijät analysoitiin: Kokonaisimmunoglobuliinit (Ig), laktoferriini (LF), laktoperoksidaasi (LP), lysotsyymi (LZM) ja Salmonella typhimurium -vasta-ainetiitteri somaattista $\left(\mathrm{O}_{4,12}\right)$ ja flagellaarista $\left(\mathrm{H}_{1,5}, \mathrm{H}_{\mathrm{j}}\right)$ antigeenia vastaan. Lisäksi määritettiin heraproteiinien (WP) kokonaismäärä.

Kaikkien tekijöiden pitoisuus vaihteli huomattavasti eri lehmien ensimmäisessä lypsyssä, mutta muiden paitsi LP ja LZM, pitoisuuserot pienenivät lypsykertojen myötä. WP-, Igja LF-pitoisuus olivat korkeimmillaan ensimmäisessä lypsyssä ja laskivat voimakkaasti seuraavissa lypsyissä. Sitä vastoin LP-pitoisuus oli keskimäärin suurin 3. ja 4. lypsykerralla ja LZMpitoisuus 7. ja 8. lypsykerralla.

Ensimmäisen lypsyn herassa olivat pitoisuudet keskimäärin seuraavat: WP $69,2 \mathrm{mg} / \mathrm{ml}$, Ig $52,0 \mathrm{mg} / \mathrm{ml}$, LF $1,53 \mathrm{mg} / \mathrm{ml}$, LP $22,8 \mu \mathrm{g} / \mathrm{ml}$ ja LZM $0,40 \mu \mathrm{g} / \mathrm{ml}$. Maidon herassa olivat pitoisuudet vastaavasti: WP $12,2 \mathrm{mg} / \mathrm{ml}, \mathrm{Ig} 0,95 \mathrm{mg} / \mathrm{ml}$, LF $0,09 \mathrm{mg} / \mathrm{ml}$, LP $20,1 \mu \mathrm{g} / \mathrm{ml}$ ja L.M $0,37 \mu \mathrm{g} / \mathrm{ml}$.

Ihmispatogeenista $S$. typhimurium-kantaa agglutinoivia vasta-aineita esiintyi sekä O- että $\mathrm{H}$-antigeeneja vastaan kaikkien lehmien ternimaidossa. Yhdellä lehmällă, joka oli rokotettu $S$. typhimuriumilla nahan alle ennen poikimista, olivat tiitterit merkittävästi korkeammat kuin ei-rokotetuilla eläimillä. Jälkimmäisillä havaittiin vasta-aineita vain kolmessa ensimmäisessä lypsyssä, kun taas rokotetulla lehmällä vasta-aineita esiintyi vielä maidossa 14 vrk poikimisen jălkeen.

Saaduista tuloksista voidaan olettaa, että vasta-aineiden lisäksi epäspesifisesti vaikuttavilla antibakteerisilla tekijōillä (LF, LP ja LZM) on merkitystä ternimaidon antimikrobiselle aktiivisuudelle ja ne voivat siten myötävaikuttaa vastasyntyneen vasikan vastustuskykyyn mikrobiinfektioita vastaan ensimmäisen elinviikon aikana. 